\title{
THE EFFECT OF VACUUM PUMP OIL ON THE CHEMOTACTIC BEHAVIOR OH'
} SOIL BACTERIA (U)

by

R.E. Dunifon and T.C. Hazen

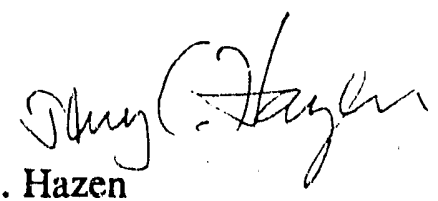

Westinghouse Savannah River Site

Savannah River Site

Aiken, South Carolina

\author{
A proposed for presentation at the \\ S.C. Junior Academy of Sciences \\ Westside High School \\ Augusta, GA \\ March 16, 1990
}

and for publication

\section{DISCLAIMER}

\begin{abstract}
This report was prepared as an account of work sponsored by an agency of the United States Government. Neither the United States Government nor any agency thereof, nor any of their employees, makes any warranty, express or implied, or assumes any legal liability or responsibility for the accuracy, completeness, or usefulness of any information, apparatus, product, or process disclosed, or represents that its use would not infringe privately owned rights. Reference herein to any specific commercial product, process, or service by trade name, trademark, manufacturer, or otherwise does not necessarily constitute or imply its endorsement, recommendation, or favoring by the United States Government or any agency thereof. The views and opinions of authors expressed herein do not necessarily state or reflect those of the United States Government or any agency thereof.
\end{abstract}

The information contained in this article was developed during the course of work under Contract No. De-AC09-88SR 18035 with the U.S. Department of Energy. By acceptance of this paper, the publisher and /or recipient acknowledges the U.S. Government's right to retain a nonexclusive, royalty-free license in and to any copyright covering this paper along with the right to reproduce, and to authorize others to reproduce all or part.

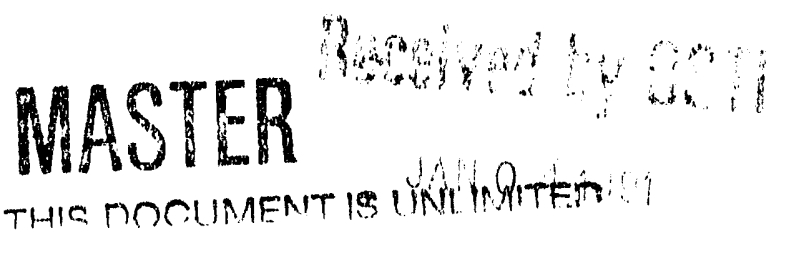


THE EFFECT OF VACUUM PUMP OIL ON THE CHEMOTACTIC BEHAVIOR OF SOIL BACTERIA $(u)$

\author{
Rachel E. Dunifon and Terry C. Hazen. Ph. D. \\ Environmental Sciences Section \\ Savannah River Laboratory \\ Westinghouse Savannah River Company \\ Aiken, South Carolina
}

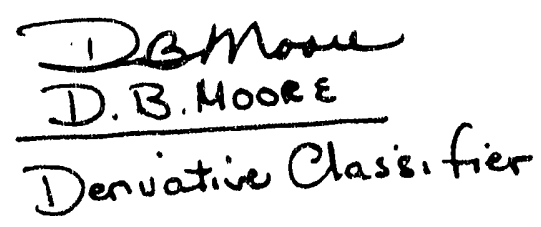




\section{ACKNOWLEDGEMENTS}

A very special thanks to John Wear for all of his time and assistance, and to Deborah King and Vivian Brown for their continuous help. Also, thanks to the Ruth Patrick Science Education Summer Science Research Program. 


\begin{abstract}
The use of biodegradation in the cleanup and transformation of waste materials is an economical and environmentally safe practice. Using chemotaxis, or the movement of bacteria toward or away from compounds. in biodegradation is an area that is being studied at the Savannah River Laboratory. This siudy investigates the inhibition of vacuum pump oil on the chemotaxis of soil bacteria. It was found that vacuum pump oil does have an inhibitory effect on the movement of bacteria. This inhibition will have to be considered when studying the possibility of using chemotaxis to degrade vacuum pump oil, or any other petroleum products.
\end{abstract}




\section{INTRODUCTION}

Biodegradation is a useful and practical way of cleaning up industrial wastes at a lower cost than traditional cleanup methods. Biodegradation is currently being used in the cleanup of wastes by taking advantage of different microbes' abilities to transform uaste compounds into less harmful substances. It has been well documented that biodegradation can be usefui in treating many kinds of petroleum wastes (Atlas, 1984).

Underground storage of petroleum, which is a common practice in industry. can be dangerous to the environment. Biodegradation of petroleum could be utilized to help solve this problem. It is estimated that there are greater than one million underground storage tanks of petroleum in the United States, and that $60 \%$ of them are probably leaking. The cleanup cost for each leaking incident is estimated to be over one million dollars (Kostecki and Calabrese, 1989). This leaking oil can easily get into the water tables of the surrounding areas. As little as one to five parts per million of the hydrocarbons found in petroleum can cause a bad taste and odor in water, and higher densities can be dangerous to man (Atlas, 1984).

Several studies have been made to determine if petroleum biodegradation is possible. Chackrabarty and General Electric patented an oil-degrading microbe that was formed by genetic breeding. However, the microbe was found to be ineffective in degrading the heavy, highly concentrated oil compounds found in the environment (Omenn, 1988). Another difficulty in degrading petroleum is that the chemical nature of petroleum is so varied that 
many different microbes are needed to make degradation effective (Omenn, 1988).

One study done at the Savannah River Laboratory investigated the degradation of vacuum pump oil (V'PO) by bacteria. Like facilities, the Savannah River Site uses a great deal of VPO. After VPO is used, an oily sludge remains. Some bacteria werc isolated from oil contaminated soils at the Savannah River Sire and a study was done at the Savannah River Laboratory to investigate the degradation of VPO by these bacteria. The study reported that the bacteria were effective in degrading VPO, and that the development of oil degrading bioreactors was a realistic possibility for the future (Sharp and Hazen, 1988).

This study continues to look at the biodegradation of VPO, using chemotaxis. Chemotaxis is movement toward or away from some chemical which allows bacteria to find that environment which provides them with the greatest supply of energy, avoid unfavorable conditions, and disperse to all those environments that are favorable. The purpose of this study is to determine if the chemotaxis of VPO toward an attractant is inhibited by the addition of VPO to the bacterial suspension. This is the first time that this question has been studied, and it will be essential in determining the feasibility of using the chemotactic movement of bacteria to degrade VPO, as well as other petroleum products. 


\section{HYPOTHESES}

1) The chemotactic movement of soil bacteria is inhibited by vacuum pump oil.

2 )Vacuum pump oil has a soluble component that is chemotactic to soil bacieria.

3) The direct count and viable count methods should give similar results if the soil bacteria remain viable. 


\section{MATERIALS AND METHODS}

Isolates: The isolates used in this experiment were; CBF 33, (a soil isolate from trichloroethylene contaminated area at the Savannah River Site), TOL-1 (a toluene degrading Escherichia coli obtained from Dr. Gary Slayor. University of Tennessee). PWWO (a Pseudomonas putida), and BO184 (an isolate from the middendorf strata sediment at Savannah River Site). The isolates were grown on PTYG media plates: $0.5 \mathrm{~g} / \mathrm{L}$ peptone, $0.5 \mathrm{~g} / \mathrm{L}$ tryptone, $1.0 \mathrm{~g} / \mathrm{L}$ yeast extract. $1.0 \mathrm{~g} / \mathrm{L}$ dextrose. $0.6 \mathrm{~g} / \mathrm{L} \quad \mathrm{MgSO}_{4}, 0.07 \mathrm{~g} / \mathrm{L} \mathrm{CaCl} 2$, and $15.0 \mathrm{~g} / \mathrm{L}$ agar (López de Vicioria. 1989).

Chemotactic Chamber: A chemotactic chamber developed by Palleroni (1976) was used in the assays. It contains 4 chambers cut in lexan measuring $5.5 \mathrm{~cm}$ per side and $1.0 \mathrm{~cm}$ thick. Each smaller chamber has 2 cylindrical compartments measuring $7.0 \mathrm{~mm}$ in height, linked by a channel $24.0 \mathrm{~mm}$ long, $2.0 \mathrm{~mm}$ wiae, and $2.0 \mathrm{~mm}$ deep (López de Victoria, 1989)(Figure 1).

Chemotaxis Assay: Isolated colonies of bacteria were taken from a plate and suspended in a flask of PTYG media broth. (Same formula as above, without agar). They were incubated for 24 hours at $20^{\circ} \mathrm{C}$ The hacterial solution was then harvested by centrifugation at $6,000 \times \mathrm{g}$ for 10 minutes at $4^{\circ} \mathrm{C}$. A pellet was formed and was resuspended in potassium phosphate buffer $(\mathrm{KPB})(\mathrm{pH} 7)$. The buffer was used to keep the $\mathrm{pH}$ of the solution stable. The pellet was suspended in the KPB and centrifuged again. This washing process was repeated once again, and after the final time the pellet was 
resuspended in KPB. KPB consists of $5.62 \mathrm{~g} / \mathrm{L} \mathrm{K} 2 \mathrm{HPO}$ and $2.13 \mathrm{~g} / \mathrm{L}$ $\mathrm{KH}_{2} \mathrm{PO}_{4}$ (López de Victoria, 1989).

The cell density of the solution was then set at $10^{8} \mathrm{cells} / \mathrm{mL}$, adding KPB to the solution to make the correct density. A motility check was done to assure that the cells were still able to move.

In the assay, the capillary method was used. A capillary tube coltaining a substrate solution was placed in the channel of the chamber, which was filled with bacterial suspension. If the bacteria are attracted to the substrate positive chemotaxis will occur, meaning that more cells will have entered that tube than the control tube, containing KPB. If the bacteria are repelled by the substance, then fewer cells will enter that tube than the control, and negative chemotaxis will have occurred.

Each compariment and channel of the chambers was filled with $0.4 \mathrm{~mL}$ of motile bacterial suspensior. $0.003 \mathrm{~mL}$ disposable micropipette (Drummond Scientific Co., Brumal Pa.) with a diameter of $0.35 \mathrm{~mm}$, was handled with tweezers and filled with $0.003 \mathrm{~mL}$ of substrate solution. The tube was then placed in the channel of the chamber with the bacterial suspension. The chambers sat for one hour at room temperature. The capillary tubes were then removed with tweezers and rinsed carefully with KPB. The tubes were then inserted in the micropipette, and the contents were released on a taxoplasmosis slide (Cel-Line Associates, Inc., N.J.) and heat-fixed.

The substrate solutions used were: KPB (as a control), $10^{-4} \mathrm{M}$ Dextrose solution, and a soluble oil solution (SOS). The SOS was made by mixing VPO and KPB, allowing it to separate into layers, then 
drawing the KPB from the bottom of the solution. Therefore, the SOS was soluble, but it also contained some oil particles.

An additional chamber was used, with the Dextrose solution in the capillary tubes. and a drop of VPO in each of the wells along with the bacterial suspension. This chamber was compared to the chamber with Dextrose in the capillary tubes and no oil in the w'ells to determine if the oil inhibited the movement of the bacteria. Dextrose was used because it is an attractant to most bacteria.

Cell Counts: After the slides containing the contents of the capillary iubes were heat-fixed, the cells were stained with Acridine Orange (Difco Laboratories. Detroit. Ml) for two minutes and washed with deionized water. The Acridine Orange Direct Count is the most accepted method of determining the total number of bacteria and is based on the attachment of the acridine orange fluorochrome to the nucleic acid within the cell. Theoretically, Acridine Orange is red only when attached to RNA, and green when attached to DNA. A Zeiss epifluorescent microscope was used for the cell counts (López de Victoria, 1989). Cell counts were done by counting the number of cells in the diameter of one well on the slide. That number was then multiplied by 78,500 (the number of diameters in one $\mathrm{mL}$ ), and the product was the total number of cells $/ \mathrm{mL}$ for that well.

Chemotactic Index: A chemotactic index was figured to determine if positive or negative chemotaxis occurred. For each substrate, the average number of cells per $\mathrm{mL}$ was calculated. This was then divided by the cellsimL for the KPB control. A number above one was considered positive chemotaxis, and a number below one indicated negative chemotaxis. 
Viability Study: A viability study was done on an assay of CBF 33. Two identical assays were run at the same time. one being used for an Acridine Orange Direct Count, and one for a Viability study. A sterile HA-96 microtiter plate (Millipore Co., Bedford, Ma.) 12 wells long and 8 wells wide was filled with $0.1 \mathrm{~mL}$ of PTYG broth in each well. Then the first eight wells had and additional $0.1 \mathrm{~mL}$ of broth added. The contents of the capillary tubes from the assay were emptied into the wells with $0.2 \mathrm{~mL}$ of broth. The $0.1 \mathrm{~mL}$ was taken from those eight wells, and added to the next column of wells. This dilution process was repeated ten more times. The plates were then allowed to sit at room temperature overnight, and the next day the turbidity, or bacterial growth, of the wells was checked. The dilution for the point at which turbidity stopped was calculated, and the number of cells per mL was determined. Then a chemotactic index was calculated as described above. The purpose of the viability study was to determine how many of the bacteria passing into the tube were still alive. 


\section{RESULTS AND DISCUSSION}

All of the isolates had a significantly lower chemotactic index when VPO was placed in the wells with dextrose in the capillary tubes (dextrose +VPO) than when no oil was placed in the wells. With TOL-1. the chemotactic index for dextrose was 0.728, and the index for dextrose + VPO was 0.486 . TOL-1 had a lower attraction to the SOS, with an index of 0.457 . The PWWO isolate had a chemotactic index of 0.752 with dextrose. It had a much lower index for dextrose + VPO, which was 0.310 . PWWO was also repelled by the SOS, although not as much as it was repelled by the dextrose + VPO, with an index of 0.53 . BO184 had a positive chemotactic attraction to dextrose, with an index of 1.14. The chemotactic index for dextrose + VPO was 0.882 . BO184 showed a severe repulsion to the SOS, with an index of 0.227 . Four assays were conducted with CBF 33 . Although the results differed occasionally, the common factor was that the chemotaxis of the bacteria was inhibited by the addition of VPO (Figure 2). In all four assays the chemotactic index was noticeably less for dextrose + VPO than it was for dextrose (Figure 3).

In two out of the four assays, CBF 33 showed a positive chemotaxis to the SOS, which none of the other isolates did. In all except the final assay, the index for the SOS was higher than the index for dextrose + VPO. Also, in the final assay of CBF 33, a mixture of dextrose and SOS was put in the capillary tubes. The chemotactic index for that mixture was lower that all of the other indexes in that assay. 
A viability study was done on the final assay of CBF 33 . The results were similar to the Acridine Orange Direct Count (AODC) in that the index for dextrose + oil was always much lower than the index for dextrose. Also, in each count CBF 33 did not have a positive response to SOS. However. the two counts differed in that the viable count showed that CBF 3 3 was attracted to Dextrose + SOS, with an index of 2.09. In the AODC the index was 0.457. In general, the indexes in the vinbility study were much hioher than those in the AODC. Ouie possible explanation for this is that the bacte ia that entered the tube containing KPB may have been stressed because of the lack of nutrients in KPB. and were then unable to grow in the brcth of the viability count. However, these stressed cells would show up in the AODC, making the number of cells $/ \mathrm{mL}$ in the AODC higher than in the viable count. Therefore, the indexes for the AODC would be much higher than the indexes in the viable count (Figure 4).

The results of this study support the hypothesis that VPO inhibits the chemotactic movement of bacteria. In each assay with each isolate, the chemotactic index was lower for dextrose + VPO than it was for dextrose. This could cause problems in the use of bacteria to regrade VPO, or any other kind of petroleum. With the chemotactic movement of the bacteria inhibited, they would not be able to move as they normally would to degrade bacteria.

Another conclusion of this study is that there may be a soluble component in VPO that is attractive to bacteria, but a non-soluble substance in VPO may be suppressing this attractic?. This relates to the different ranges of positive and negative chemotactic responses 
of the different isolates to the SOS. Further study is needed in this area to support this data.

In each cell count, the number of green and red cells was recorded. The red cells were in the process of protein production, and were considered to be actively growing. A percentage of active cells was calculated. In most cases. the KPB and dextrose + VPO had the lowest numbers of actively growing cells, but there is not sufficient evidence to make any conclusions (figures 5\&6). 


\section{CONCLUSIONS}

1) Vacuum pump oil inhibits the chemotactic movement of bacteria.

2) There is a soluble substance in vacuum pump oil that may be an attractant to some bacteria, however this attraction may be repressed in some bacteria by non-soluble components.

3) The results of the viability count also demonstrated that oil inhibits bacterial movement and ronfirmed that the bacteria were remaining active and viable.

4) The large chemotactic indexes obtained in the viable count suggests that the KPB alone stresses the bacteria, thus reducing recovery. 


\section{BIBLIOGRAPHY}

Atlas, Ronald M., Petroleum Microbiologle- Macmillan

Publishing Co., New York:1984, pp.442-450.

Kostecki, Paul T. and Edward Calabrese, Petrolcum

Contaminated Soils, Lewis Publishers, Chelsea. Ml: 1989. pr. 28.5. 288.

Omenn, Gilbert S., Environmental Bintechnology. Plenum Press, New York:1988, pp.213-217.

Sharp, Jamie:Biodegradation of Vacuum Pump Oil by Naturally' Occurring Bacteria, Savannah River Laboratory, 1988.

López de Victoria, Geralyne:Chemotactic Behavior of Deep Subsurface Bacteria Toward Carbohydrates, Amino Acids, and a Chlorinated Alkene, Masters thesis, Savannah River Laboratory, 1989. 
Chemotaxis Chamber
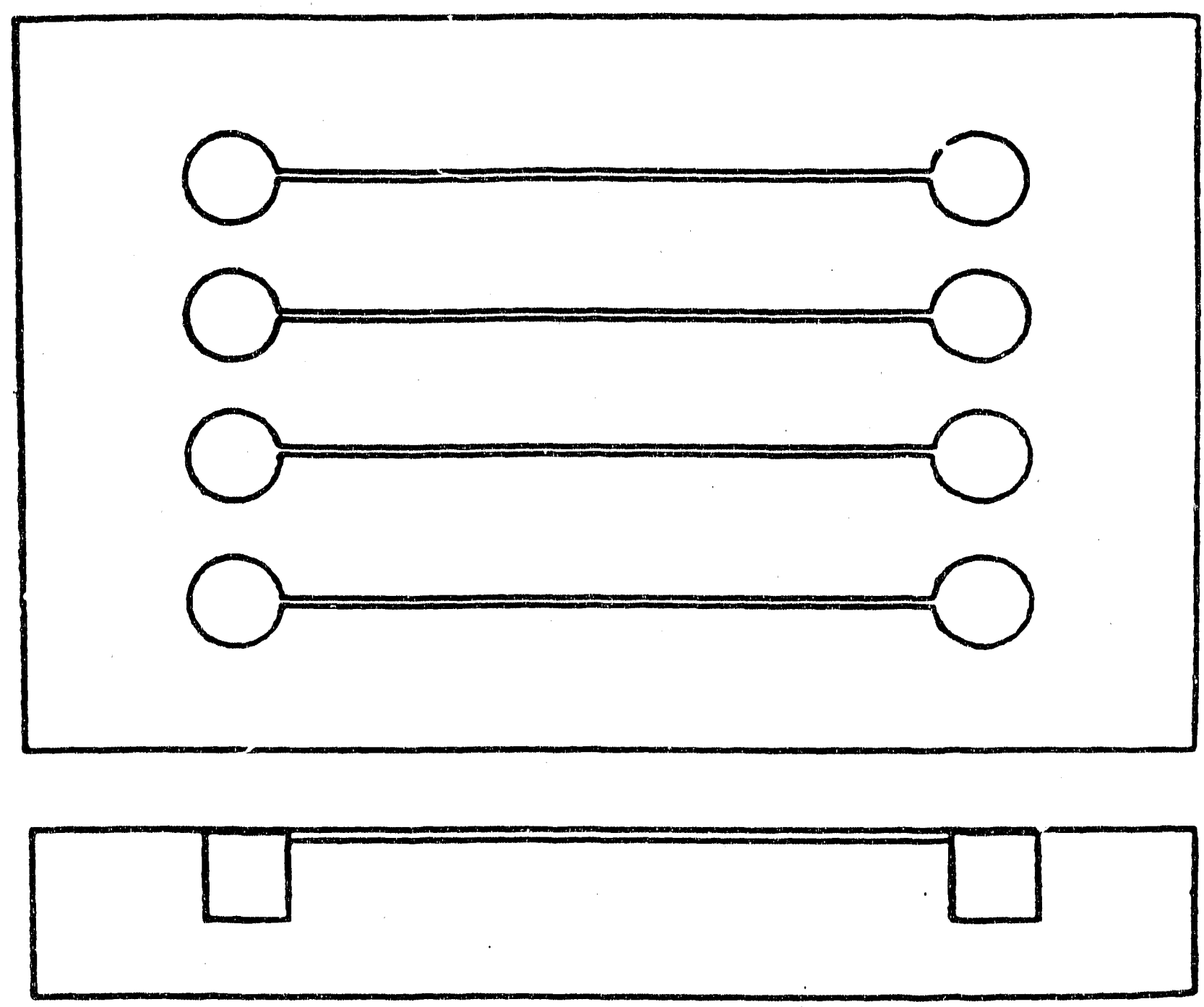

Palleroni, 197.

Figure Chemotactic chamber (Palleroni, 1976). 


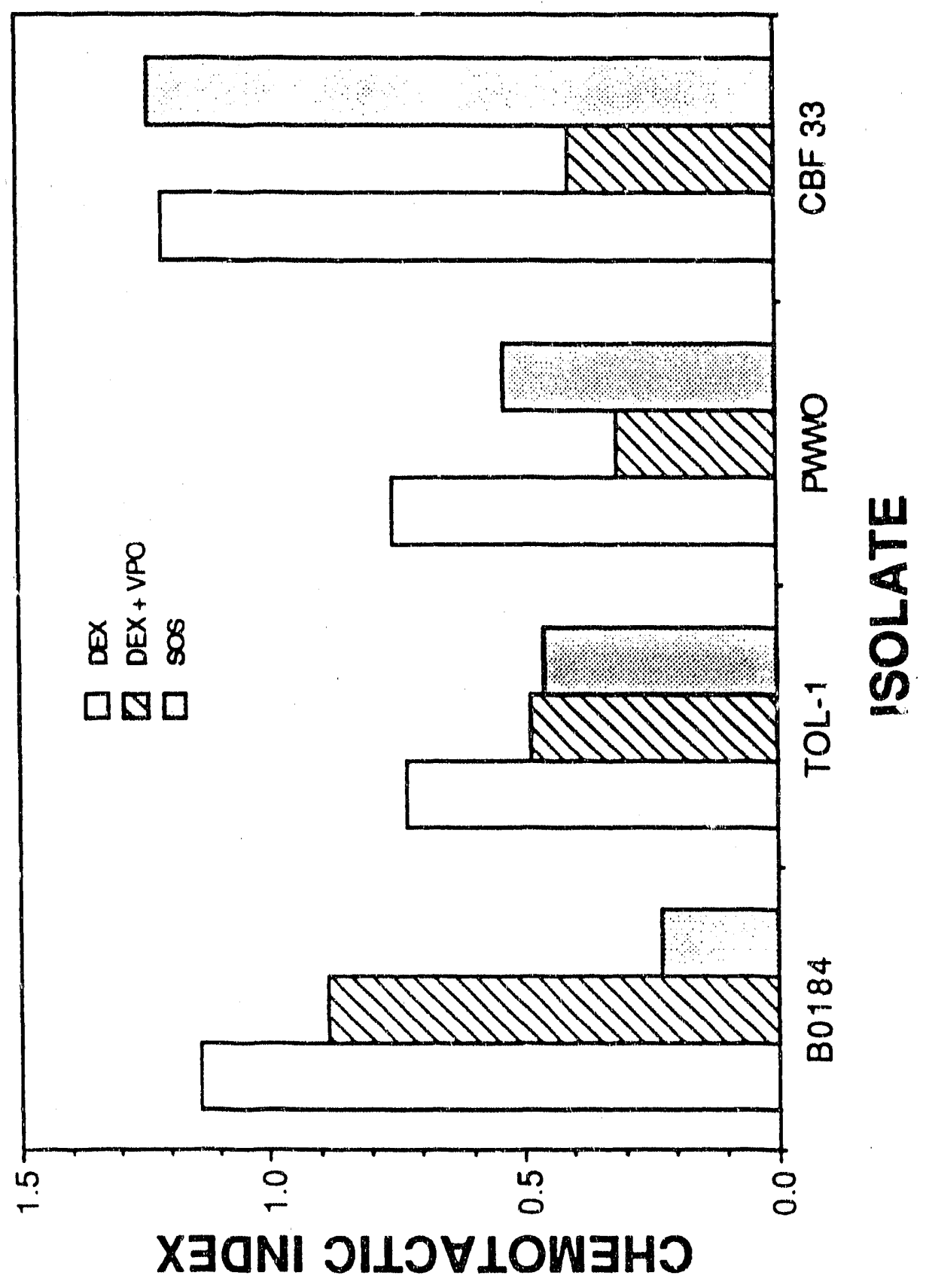

$d$

$\therefore$ 


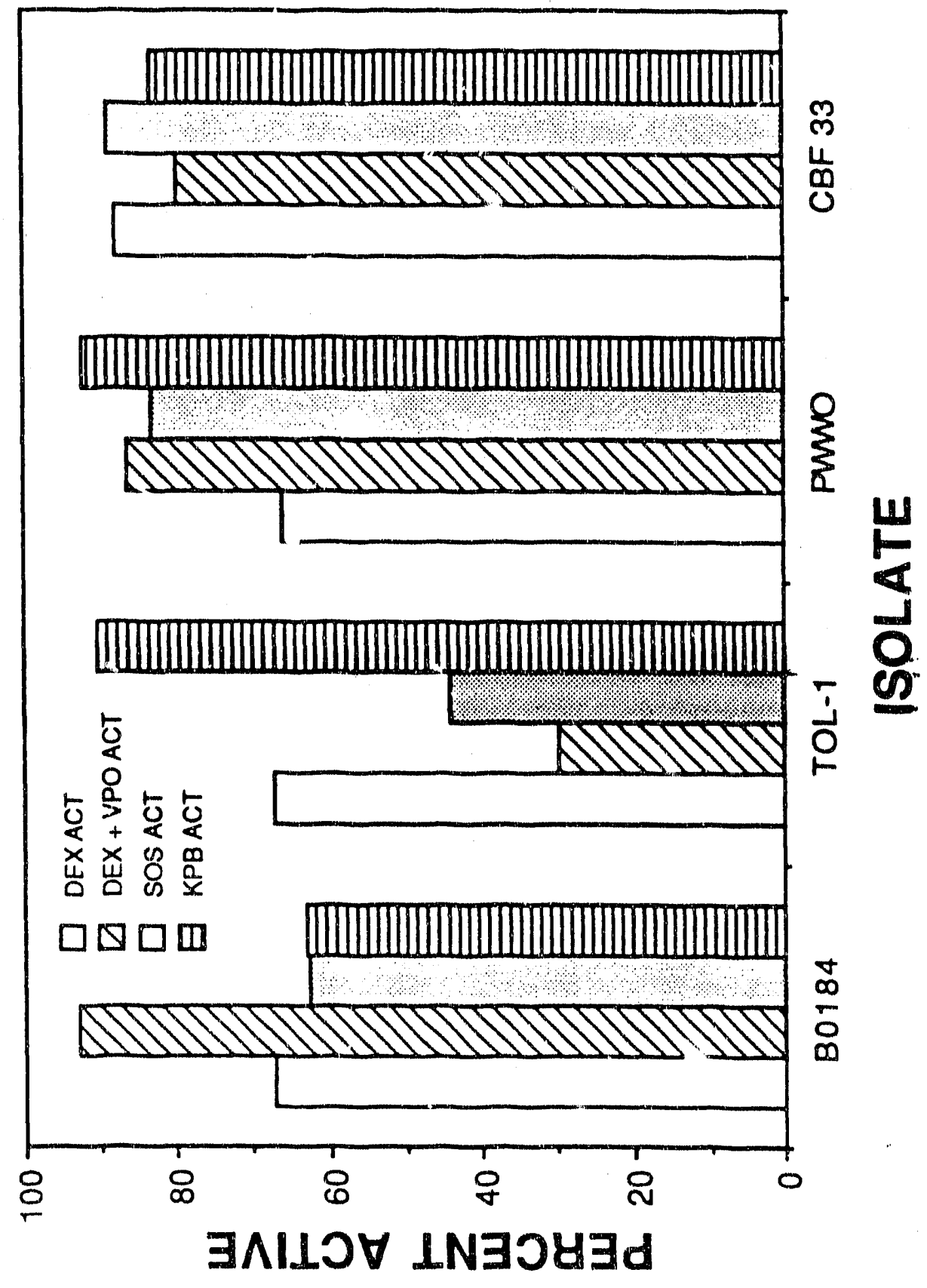




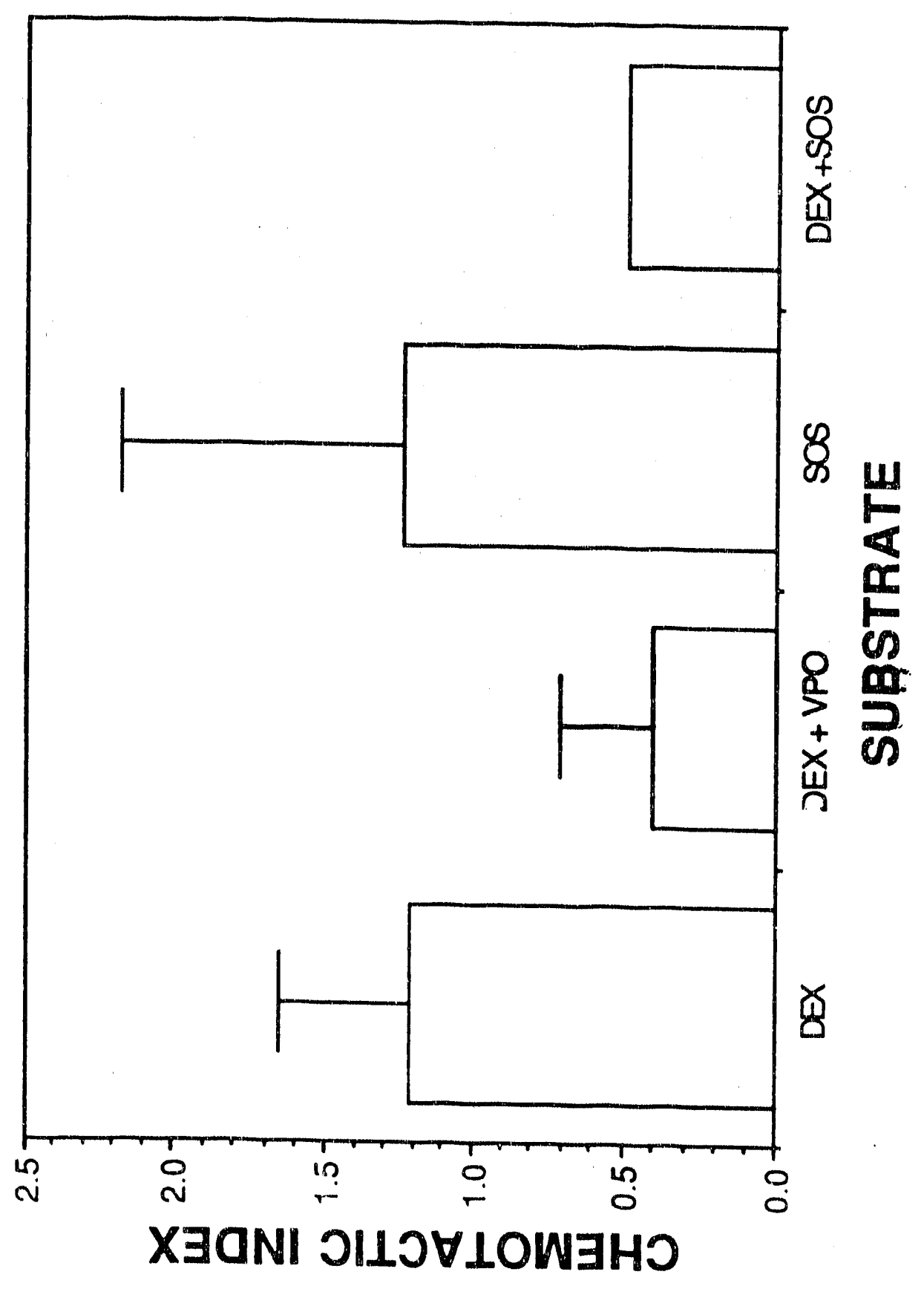

$x$

$\therefore$ 


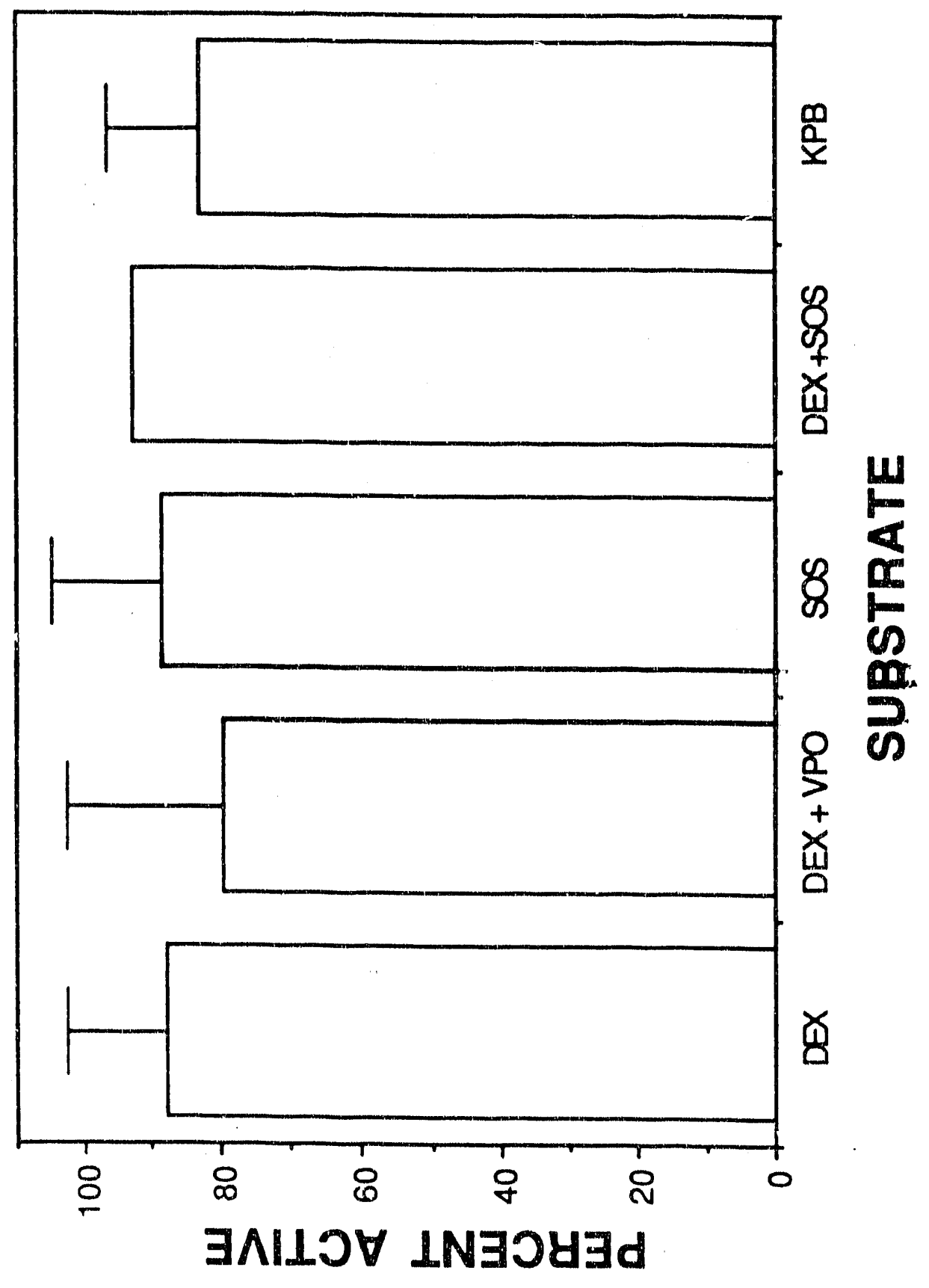



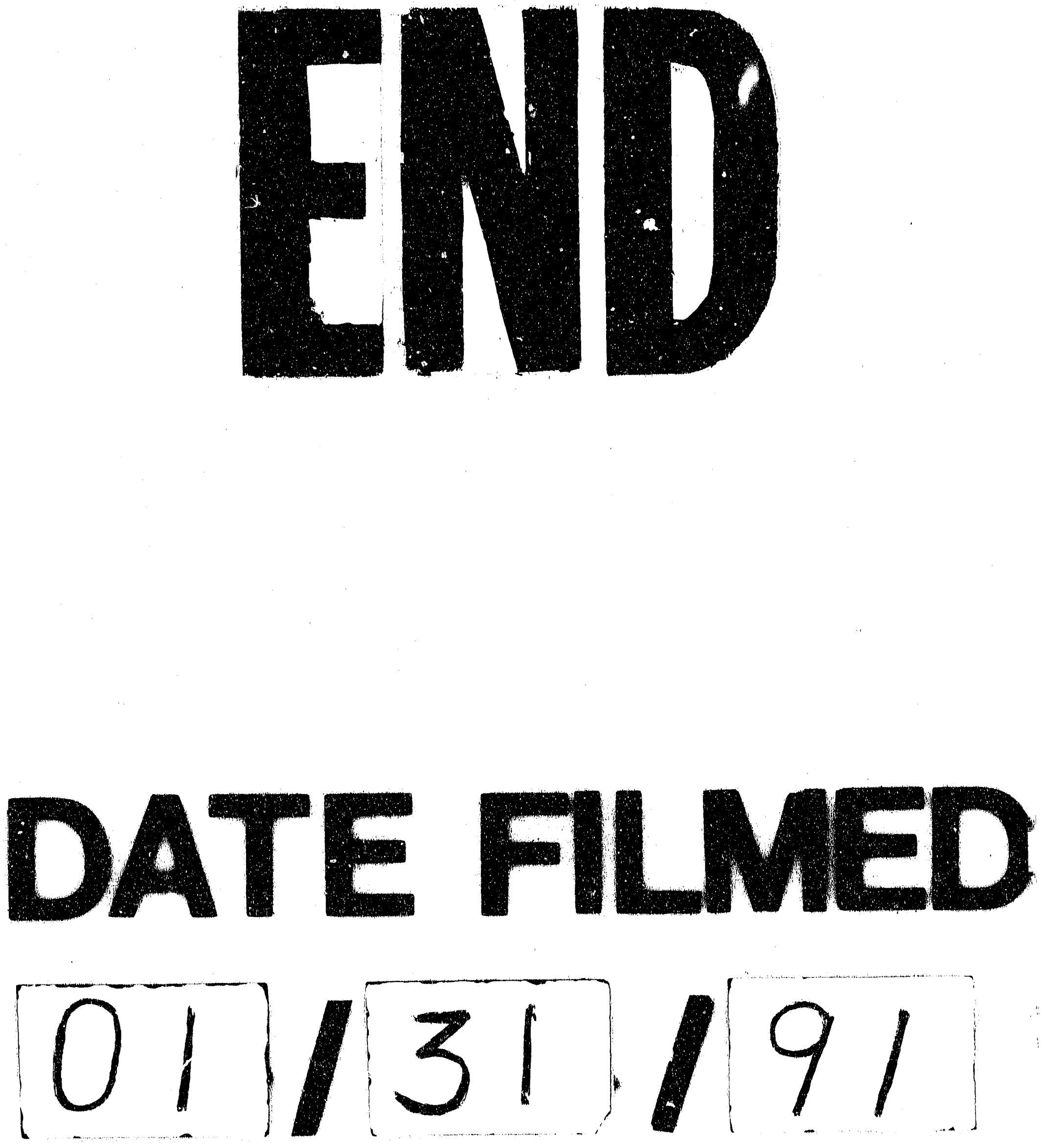
